\title{
Effects of Mixing and Curing Temperature on the Strength Development and Pore Structure of Fly Ash Blended Mass Concrete
}

\author{
Ki-Bong Park ${ }^{1}$ and Takafumi Noguchi ${ }^{2}$ \\ ${ }^{1}$ Department of Architectural Engineering, College of Engineering, Kangwon National University, Chuncheon-si, Republic of Korea \\ ${ }^{2}$ Department of Architecture, Graduate School of Engineering, The University of Tokyo, Tokyo, Japan \\ Correspondence should be addressed to Ki-Bong Park; kbpark@kangwon.ac.kr
}

Received 19 December 2016; Accepted 1 March 2017; Published 20 March 2017

Academic Editor: Xiao-Jian Gao

Copyright (C) 2017 Ki-Bong Park and Takafumi Noguchi. This is an open access article distributed under the Creative Commons Attribution License, which permits unrestricted use, distribution, and reproduction in any medium, provided the original work is properly cited.

\begin{abstract}
The aim of this work is to know clearly the effects of temperature in response to curing condition, hydration heat, and outside weather conditions on the strength development of high-performance concrete. The concrete walls were designed using three different sizes and three different types of concrete. The experiments were conducted under typical summer and winter weather conditions. Temperature histories at different locations in the walls were recorded and the strength developments of concrete at those locations were measured. The main factors investigated that influence the strength developments of the obtained samples were the bound water contents, the hydration products, and the pore structure. Testing results indicated that the elevated summer temperatures did not affect the early-age strength gain of concrete made using ordinary Portland cement. Strength development was significantly increased at early ages in concrete made using belite-rich Portland cement or with the addition of fly ash. The elevated temperatures resulted in a long-term strength loss in both belite-rich and fly ash containing concrete. The long-term strength loss was caused by a reduction in the degree of hydration and an increase in the total porosity and amount of smaller pores in the material.
\end{abstract}

\section{Introduction}

High-performance concrete is being used increasingly in the construction of high-rise buildings, bridges and marine structures. If high strength concrete is used for columns or other large section members of massive concrete structures, the center temperature of the members will rise rapidly at early ages due to hydration heat and the high temperatures will remain in the member for a relatively long period of time due to the low thermal conductivity of concrete. High temperatures generally accelerate the early-age strength development of concrete, while reducing the long-term strength development. These elevated temperatures will result in physical and chemical transformations in the concrete [17]. Various researchers have studied the microstructure and hydration to explain these effects. It has been reported that the loss of long-term strength is induced by both physical effects and chemical effects. The physical effects are an increase in porosity and an increased incidence of microcracking in cement paste, the latter caused by large differences in the thermal expansion coefficients of the concrete constitutes [818]. The chemical effects include changes in the structure of the hydration products and the loss of water in concrete [19-24]. Most of the research on cement paste, mortar, and concrete was conducted with the specimens hydrated at room temperature, on a level surface and during the early stages of hydration. There is not enough information available on high-performance concrete curd at elevated temperatures, in mass structures. Studies on the effects of outside weather conditions on the strength development of high-performance concrete in mass structures are very scarce in the technical literature.

This research provided the data needed to set a limitation on the maximum permissible internal temperature of a mass structure, such as a nuclear facility structure, a bridge foundation, or a marine structure, to ensure the structure is strong 
TABLE 1: Bogue composition of cement used in concretes.

\begin{tabular}{lcccccc}
\hline \multirow{2}{*}{ Cement } & \multirow{2}{*}{ Blaine $\left(\mathrm{cm}^{2} / \mathrm{g}\right)$} & \multirow{2}{*}{ Density $\left(\mathrm{g} / \mathrm{cm}^{3}\right)$} & \multicolumn{3}{c}{ Mineralogical properties (\%) } \\
\hline OPC & 3280 & 3.16 & $\mathrm{C}_{3} \mathrm{~S}$ & $\mathrm{C}_{2} \mathrm{~S}$ & $\mathrm{C}_{3} \mathrm{~A}$ & 9 \\
$\mathrm{BPC}$ & 4080 & 3.20 & 29 & 24 & 9 & 3 \\
\hline
\end{tabular}

TABle 2: Properties of fly ash.

\begin{tabular}{|c|c|c|c|c|c|c|c|}
\hline \multirow[b]{2}{*}{ Ig. loss (\%) } & \multirow[b]{2}{*}{ Specific gravity } & \multicolumn{2}{|c|}{ Fineness } & \multirow[b]{2}{*}{$\begin{array}{l}\text { Percentage of } \\
\text { flow }(\%)\end{array}$} & \multirow[b]{2}{*}{$\mathrm{SiO}_{2}(\%)$} & \multirow[b]{2}{*}{$\mathrm{CaO}(\%)$} & \multirow[b]{2}{*}{$\mathrm{Al}_{2} \mathrm{O}_{3}(\%)$} \\
\hline & & $\begin{array}{c}45 \mu \mathrm{m} \text { sieve residual } \\
\text { quantity (\%) }\end{array}$ & $\begin{array}{l}\text { Blaine } \\
\left(\mathrm{cm}^{2} / \mathrm{g}\right)\end{array}$ & & & & \\
\hline 0.9 & 2.27 & 2.3 & 3890 & 110 & 33.2 & 42.3 & 14.1 \\
\hline
\end{tabular}

TABLE 3: Mix proportions and properties in fresh concrete.

\begin{tabular}{|c|c|c|c|c|c|c|c|}
\hline \multirow{2}{*}{ Concrete } & \multirow{2}{*}{$\mathrm{W} / \mathrm{C}$} & \multirow{2}{*}{ S/A } & \multicolumn{5}{|c|}{ Unit content $\left(\mathrm{kg} / \mathrm{m}^{3}\right)$} \\
\hline & & & Water & Cement & Fly ash & Sand & Gravel \\
\hline OPC-S & 0.33 & 0.49 & 170 & 516 & - & 787 & 840 \\
\hline BPC-S & 0.33 & 0.53 & 170 & 516 & - & 854 & 776 \\
\hline FPC-S & 0.33 & 0.50 & 170 & 310 & 206 & 774 & 776 \\
\hline OPC-W & 0.33 & 0.49 & 170 & 516 & - & 787 & 840 \\
\hline BPC-W & 0.33 & 0.53 & 170 & 516 & - & 854 & 776 \\
\hline FPC-W & 0.33 & 0.50 & 170 & 310 & 206 & 774 & 776 \\
\hline 0.49 & 0.49 & 0.49 & 0.49 & 0.49 & 0.49 & 0.49 & 0.49 \\
\hline Concrete & S/A & Chemical agent $^{* 1}$ & Chemical agent $^{* 2}$ & Slump $(\mathrm{cm})$ & Flow $(\mathrm{cm})$ & Air (\%) & Temp. $\left({ }^{\circ} \mathrm{C}\right)$ \\
\hline OPC-S & 0.49 & $\mathrm{C} \times 1.2 \%$ & $\mathrm{C} \times 0.001 \%$ & 22.0 & 38.5 & 4.9 & 31 \\
\hline BPC-S & 0.53 & $\mathrm{C} \times 1.3 \%$ & - & & 63.5 & 4.8 & 30 \\
\hline FPC-S & 0.50 & $\mathrm{C} \times 1.0 \%$ & - & & 63.0 & 4.4 & 30.5 \\
\hline OPC-W & 0.49 & $\mathrm{C} \times 1.2 \%$ & $\mathrm{C} \times 0.001 \%$ & 23.5 & 42.0 & 4.1 & 8.5 \\
\hline BPC-W & 0.53 & $\mathrm{C} \times 1.3 \%$ & - & & 61.5 & 4.2 & 10 \\
\hline FPC-W & 0.50 & $\mathrm{C} \times 1.0 \%$ & - & & 61.2 & 4.2 & 8.5 \\
\hline
\end{tabular}

${ }^{* 1}$ High range water reducing agent, $\mathrm{SP} 8 \mathrm{SX}_{2} \cdot{ }^{* 2}$ Air reducing agent, MA404.

and durable. In this paper we will report on some experimental work investigating the compressive strength gain at varying temperatures during the mixing, placing, and curing of concrete in mass structures. Concrete walls were designed having three different depths, being $1.5 \mathrm{~m}, 0.8 \mathrm{~m}$, and $0.3 \mathrm{~m}$, composed of three different types of concrete, and processed under two different climate conditions. Temperature histories at different locations in the walls were recorded and the compressive strength, the degree of hydration products, and the microstructure of the concrete at those locations are presented.

\section{Experimental Design}

2.1. Mixing and Materials. Three types of concrete were used in this study: concrete made with ordinary Portland cement (OPC), with belite-rich Portland cement (BPC), and with ordinary Portland cement supplemented with $40 \%$ fly ash (FPC). This level of fly ash has been increasingly used for high-performance concrete in mass structures. The properties of the cement are shown in Table 1. Fly ash conforming to JIS A 6201 had the properties as given in Table 2. The aggregate consisted of crushed sandstone (maximum size: $20 \mathrm{~mm}$, density: $2.65 \mathrm{~g} / \mathrm{cm}^{3}$, absorption: $0.72 \%$, and fineness modulus: 6.0 ) and construction sand (density: $2.58 \mathrm{~g} / \mathrm{cm} 3$, absorption: $2.07 \%$, and fineness modulus: 2.69 ). An air reducing agent and a high range water reducing agent were used as admixtures. Their amounts are given in Table 3 . The concrete was mixed in a twin shaft-type mixer $(200 \mathrm{~L})$. After first mixing the mortar for $50 \mathrm{sec}$., the coarse aggregate was added and the resulting concrete was mixed for another 90 seconds. The mixing was conducted in the summer and in the winter to provide the two types of weather conditions. In Table 3, the composition and the properties of the fresh concrete are presented.

2.2. Design of Model Walls and Curing. To investigate the variation of long-term strength in actual concrete walls subjected to different curing temperatures, three model walls were designed. The model walls are shown in Figure 1. The depths of the walls were similar to those in an actual nuclear power plant, namely, $1.5 \mathrm{~m}, 0.8 \mathrm{~m}$, and $0.3 \mathrm{~m}$. In order to simulate an actual long wall, the circumference of the wall's 
TABLE 4: Compressive strength data of concretes.

\begin{tabular}{|c|c|c|c|c|c|c|c|c|c|c|c|}
\hline \multirow{2}{*}{ Concrete (summer) } & \multirow{2}{*}{ Curingstates } & \multicolumn{4}{|c|}{ Compressive strength (MPa) } & \multirow{2}{*}{ Concrete (Winter) } & \multirow{2}{*}{ Curing states } & \multicolumn{4}{|c|}{ Compressive strength $(\mathrm{MPa})$} \\
\hline & & 3 days & 7 days & 28 days & 91 days & & & 3 days & 7 days & 28 days & 91 days \\
\hline \multirow{7}{*}{ OPC-S } & Standard & 47.9 & 59.2 & 69.7 & 78.9 & \multirow{7}{*}{ OPC-W } & Standard & 51.4 & 65.5 & 78.8 & 82.4 \\
\hline & Sealed & 43.8 & 54.6 & 60.5 & 69.7 & & Sealed & 46.0 & 57.7 & 68.4 & 74.5 \\
\hline & $1.5 \mathrm{~m}-\mathrm{C}$ & 51.7 & 55.8 & 60.3 & 60.9 & & $1.5 \mathrm{~m}-\mathrm{C}$ & 64.0 & 71.7 & 73.7 & 74.0 \\
\hline & $1.5 \mathrm{~m}-\mathrm{S}$ & 47.9 & 49.2 & 59.2 & 60.3 & & $1.5 \mathrm{~m}-\mathrm{S}$ & 56.7 & 58.3 & 72.1 & 72.9 \\
\hline & $0.8 \mathrm{~m}-\mathrm{C}$ & & & 54.9 & 58.7 & & $0.8 \mathrm{~m}-\mathrm{C}$ & & & 72.1 & 74.6 \\
\hline & $0.8 \mathrm{~m}-\mathrm{S}$ & & & 56.3 & 59.5 & & $0.8 \mathrm{~m}-\mathrm{S}$ & & & 70.3 & 74.0 \\
\hline & $0.3 \mathrm{~m}-\mathrm{C}$ & & & 57.8 & 62.6 & & $0.3 \mathrm{~m}-\mathrm{C}$ & & & 67.8 & 69.8 \\
\hline \multirow{7}{*}{ BPC-S } & Standard & 33.9 & 45.8 & 74.4 & 87.5 & \multirow{7}{*}{ BPC-W } & Standard & 34.6 & 49.4 & 81.2 & 90.1 \\
\hline & Sealed & 33.8 & 41.0 & 63.9 & 81.0 & & Sealed & 33.3 & 43.0 & 66.6 & 77.2 \\
\hline & $1.5 \mathrm{~m}-\mathrm{C}$ & 60.7 & 63.8 & 64.6 & 69.3 & & $1.5 \mathrm{~m}-\mathrm{C}$ & 56.2 & 64.4 & 75.1 & 78.6 \\
\hline & $1.5 \mathrm{~m}-\mathrm{S}$ & 48.5 & 58.0 & 62.6 & 65.7 & & $1.5 \mathrm{~m}-\mathrm{S}$ & 37.0 & 44.4 & 61.5 & 73.0 \\
\hline & $0.8 \mathrm{~m}-\mathrm{C}$ & & & 67.5 & 70.1 & & $0.8 \mathrm{~m}-\mathrm{C}$ & & & 66.8 & 70.1 \\
\hline & $0.8 \mathrm{~m}-\mathrm{S}$ & & & 64.2 & 69.4 & & $0.8 \mathrm{~m}-\mathrm{S}$ & & & 60.6 & 73.8 \\
\hline & $0.3 \mathrm{~m}-\mathrm{C}$ & & & 67.7 & 70.4 & & $0.3 \mathrm{~m}-\mathrm{C}$ & & & 58.7 & 72.2 \\
\hline \multirow{7}{*}{ FPC-S } & Standard & 26.6 & 38.7 & 55.0 & 70.1 & \multirow{7}{*}{ FPC-W } & Standard & 28.4 & 42.5 & 59.1 & 75.7 \\
\hline & Sealed & 22.8 & 34.5 & 48.9 & 65.4 & & Sealed & 28.3 & 35.2 & 47.7 & 59.6 \\
\hline & $1.5 \mathrm{~m}-\mathrm{C}$ & 46.9 & 52.7 & 55.5 & 54.0 & & $1.5 \mathrm{~m}-\mathrm{C}$ & 38.3 & 55.9 & 57.6 & 62.7 \\
\hline & $1.5 \mathrm{~m}-\mathrm{S}$ & 39.9 & 46.8 & 52.3 & 55.5 & & $1.5 \mathrm{~m}-\mathrm{S}$ & 26.8 & 39.7 & 47.7 & 57.8 \\
\hline & $0.8 \mathrm{~m}-\mathrm{C}$ & & & 50.8 & 56.1 & & $0.8 \mathrm{~m}-\mathrm{C}$ & & & 51.2 & 64.3 \\
\hline & $0.8 \mathrm{~m}-\mathrm{S}$ & & & 53.5 & 58.7 & & $0.8 \mathrm{~m}-\mathrm{S}$ & & & 48.3 & 56.1 \\
\hline & $0.3 \mathrm{~m}-\mathrm{C}$ & & & 55.0 & 59.2 & & $0.3 \mathrm{~m}-\mathrm{C}$ & & & 46.0 & 64.6 \\
\hline
\end{tabular}

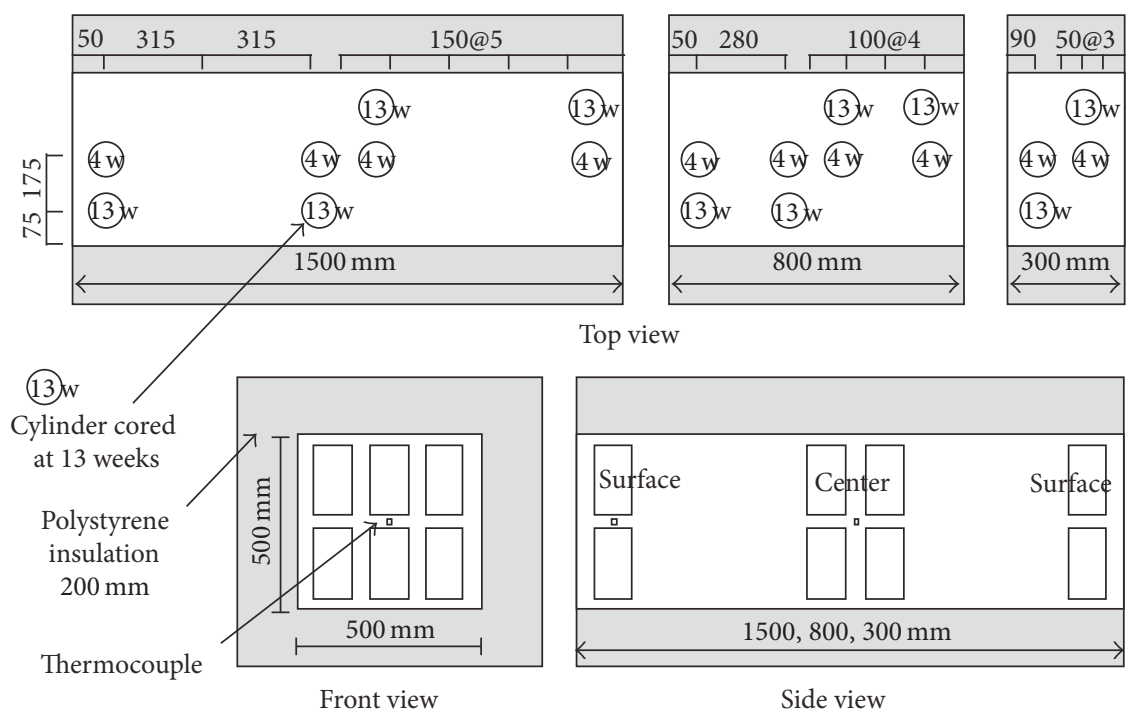

FIGURE 1: Model walls and position of tests.

depths direction was insulated with a layer of $200 \mathrm{~mm}$ thick polystyrene and the square surfaces of the wall were exposed to the open air. The walls were cast in $20 \mathrm{~mm}$ plywood formwork. The formwork was removed at 72 hours after casting. Core cylinders $(100 \times 200 \mathrm{~mm})$ were taken from the walls at 3, 7, 28, and 91 days and used for compressive strength, pore structure, and hydration products measurements. For comparison, concrete cylinders were also cast in steel molds.
All cylinders were removed from the steel molds 24 hours after casting. Sealed cylinders were sealed in polyethylene sheeting and then stored in a curing room at $20^{\circ} \mathrm{C}$. The standard cured cylinders were stored in water at $20^{\circ} \mathrm{C}$.

2.3. Testing Procedure. Temperature histories at different locations in the walls were recorded using thermocouples, shown in Figure 1. Cores, standard, and sealed cylinders were 

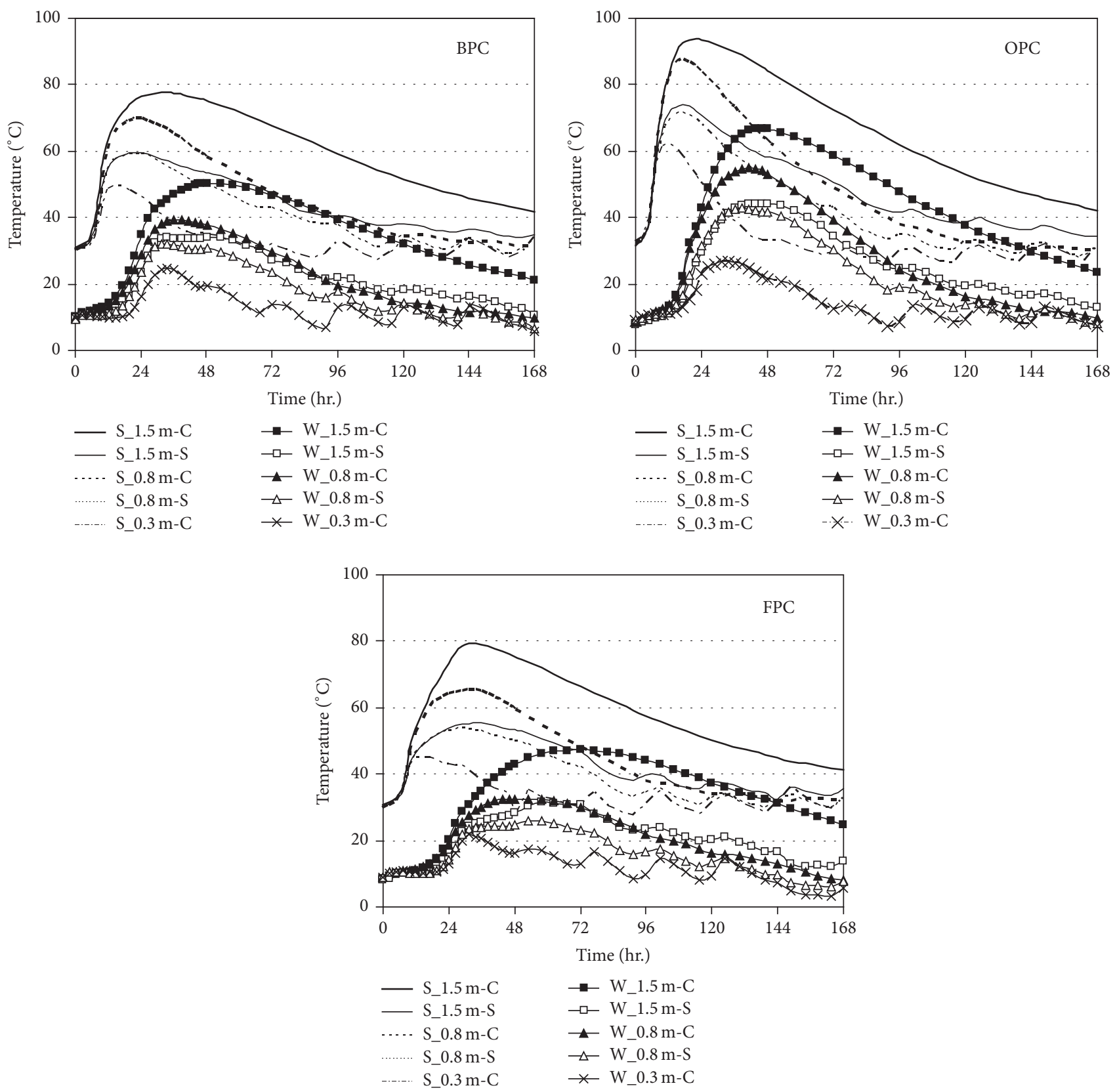

Figure 2: Temperature history in model walls. (S_1.5 m-C = S: summer, $1.5 \mathrm{~m}$ : size, C: center, W_1.5 m-S = W: winter, 1.5: size, and S: surface).

tested for compressive strength at 3, 7, 28, and 91 days. A portion of the concrete cylinders were cut into approximately $5 \mathrm{~mm}$ cubes using a diamond saw. These fragments were immediately immersed in acetone to prevent further hydration. Thereafter, all fragments were D-dried for about 2 weeks. Then the fragments were carefully ground by hand until a sample powder was obtained, which could pass through a $45 \mu \mathrm{m}$ sieve and was suitable for the determination of calcium hydroxide $(\mathrm{CH})$ contents and bound water contents. The amount of calcium hydroxide was determined by differential scanning calorimeter (DSC). The amount of calcium hydroxide was determined by ignition loss experiments. The porosity and pore size distribution were determined using mercury intrusion porosimetry (MIP). The pressure applied ranged from zero to $240 \mathrm{MPa}$. The $5 \mathrm{~mm}$ cubes for MIP measurements were also D-dried for about 2 weeks before testing.

\section{Test Results and Discussion}

3.1. Temperature Development. The temperature histories in the concrete walls are shown in Figure 2. In summer (temp. $\left.32^{\circ} \mathrm{C}\right)$, the maximum temperature at the center of the $1.5 \mathrm{~m}$ deep walls made with OPC, BPC, and FPC was $94^{\circ} \mathrm{C}$, $78^{\circ} \mathrm{C}$, and $80^{\circ} \mathrm{C}$ respectively. The maximum temperature was achieved at 22 hours after casting in OPC and, at 31 hours 

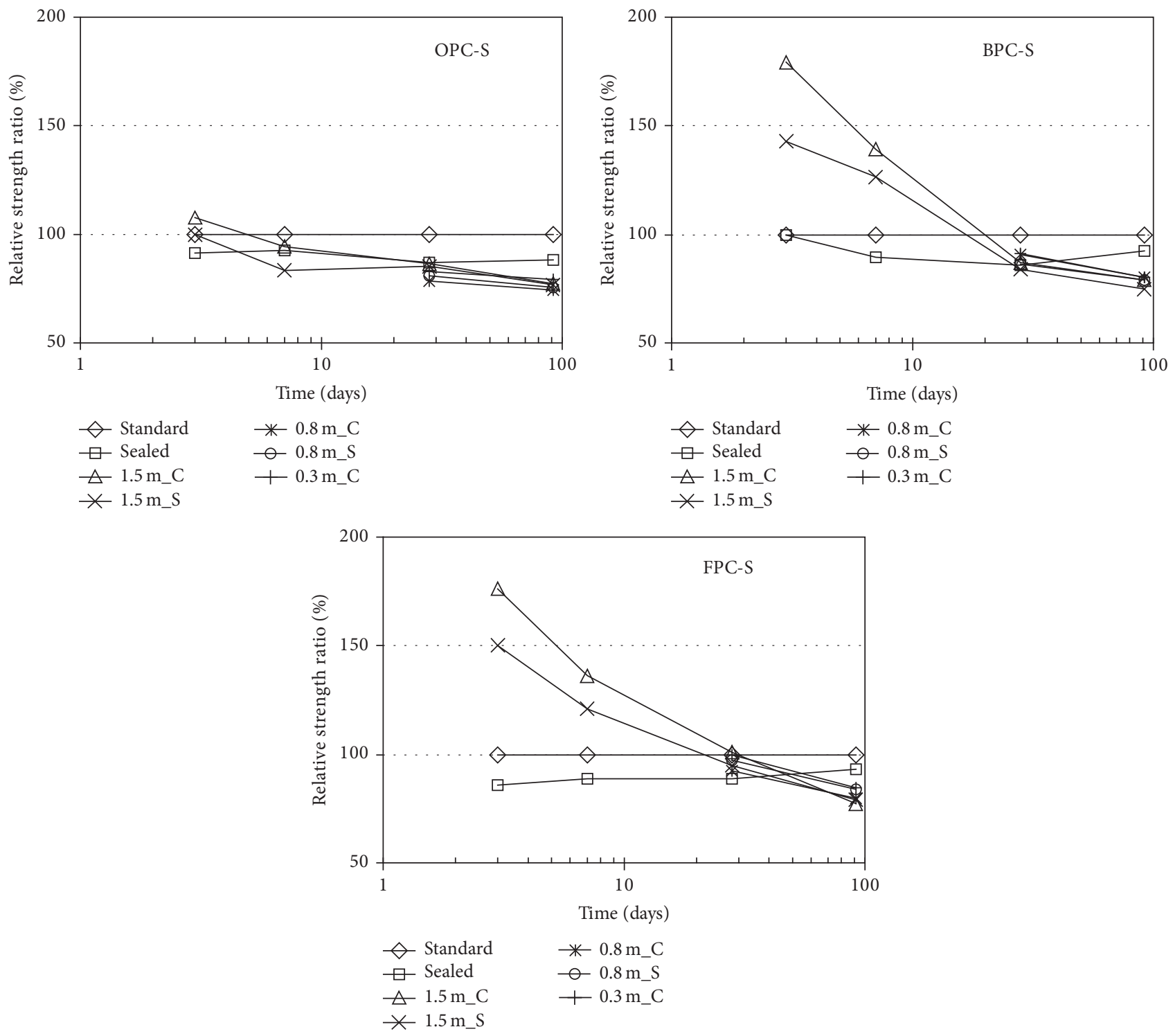

FiguRE 3: Effect of temperature on strength development of concrete at summer.

after casting in BPC, and FPC was achieved at 34 hours. The maximum temperature at the surface of the same members was $74^{\circ} \mathrm{C}, 60^{\circ} \mathrm{C}$, and $55^{\circ} \mathrm{C}$ respectively. The temperature differential between the center and the surface of the concrete was greatest in the FPC mix. The temperature rise in FPC walls was smaller than that of BPC walls, except at the center of $1.5 \mathrm{~m}$ deep wall. The $1.5 \mathrm{~m}$ FPC walls showed a significant increase in temperature due to an increase in the rate of the pozzolanic reaction of fly ash. This can be attributed to the latent hydraulic properties inherent in fly ash. According to Fraay et al. [25], the glass material in fly ash is broken down when the $\mathrm{pH}$ value of the pore water is at least about 13.2. The increase in alkalinity required for the fly ash reaction is achieved through the reaction of the Portland cement. Accordingly, the slower hydration results in a more gradual development in temperature. Additionally, the high elevated temperature in the FPC wall was sustained for a relatively long period of time. Under winter condition (temp. $9^{\circ} \mathrm{C}$ ), the temperature histories obtained in each wall's location reflected the difference in outside temperature between summer and winter. The initial mixing temperature significantly affected the maximum peak temperature and the retardation period.

3.2. Compressive Strength Development. The compressive strengths of core, standard, and sealed specimens of concrete made under summer and winter conditions are listed in Table 4. The compressive strength of the standard specimen cured in water at $20^{\circ} \mathrm{C}$ was higher than that of the sealed specimen. It is generally known that a low water to ratio in concrete mix leads to the possibility of selfdesiccation and limitations on continued cement hydration, which explains the differing strength between specimens. Thus, the availability of external water is required to enable 

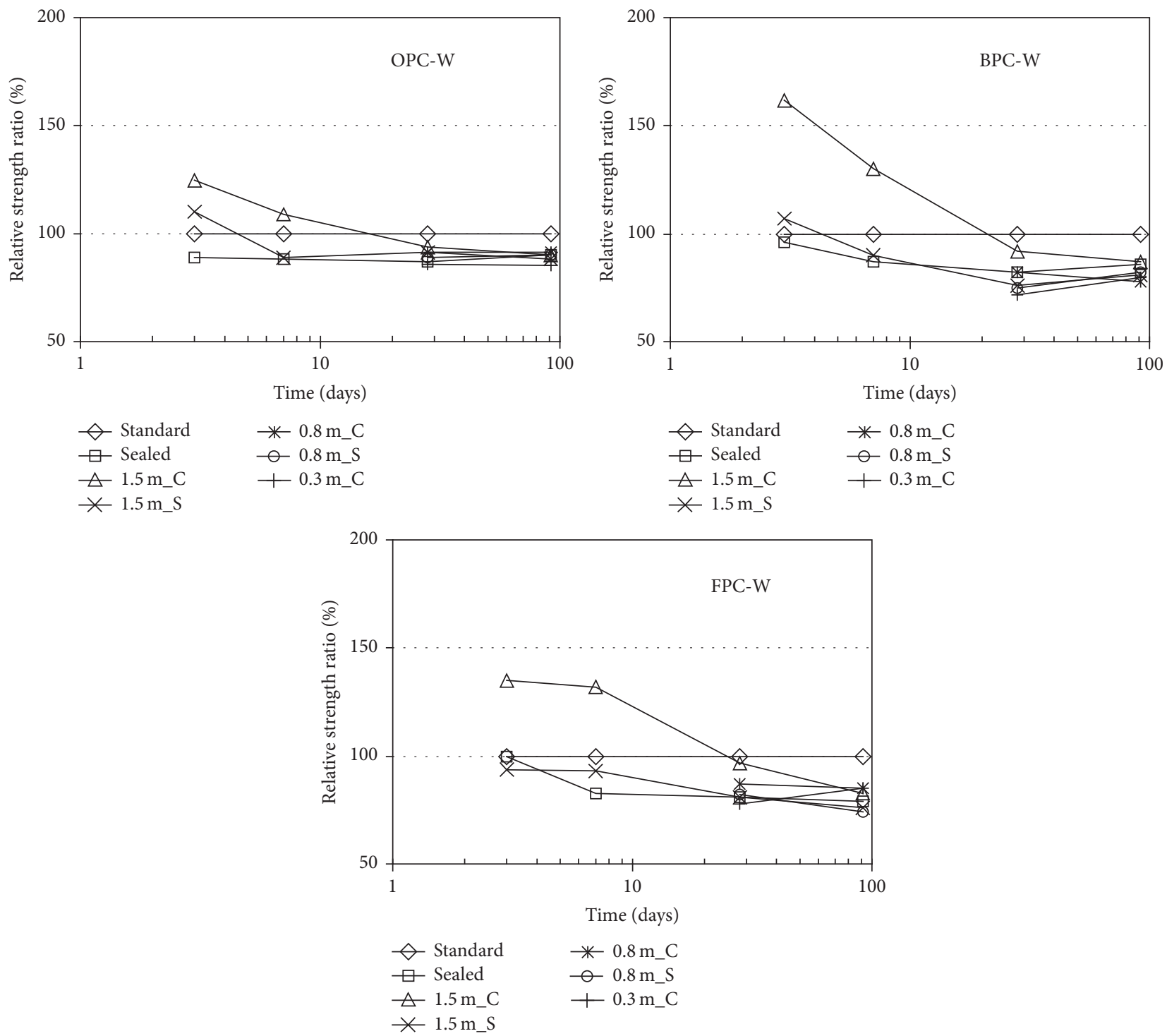

FIGURE 4: Effect of temperature on strength development of concrete at winter.

hydration to continue uninhibited. The strength development of concrete made under winter weather conditions was faster than that of concrete made under summer conditions, both for the standard and sealed specimens. These results are very interesting because we usually thought the high mixing temperature increases the compressive strength at early ages. The compressive strength of the core specimen was higher than that of the standard specimen at early ages due to the higher temperatures attained in core. However, the $1.5 \mathrm{~m}$ depth wall made under summer conditions using OPC behaved differently. In this sample, the elevated temperature did not affect the strength development at any age. In OPC, the strength of the core specimen made under winter conditions was significantly higher than the comparable specimen made under summer conditions. Such was not the case for the concrete made with BPC and FPC. In these samples, the strength of the core specimens made under winter conditions was lower than those made under summer conditions. In the summer, core strength of BPC samples was significantly increased at all ages regardless of the size of the walls. However, in the winter, the strength development of BPC was lower than that of OPC, except for the core specimen at the center of the $1.5 \mathrm{~m}$ deep wall at the longest ages.

The influence of temperature on the compressive strength can be clearly described in terms of a relative strength ratio defined against the strength of a standard specimen cured in water at $20^{\circ} \mathrm{C}$. Using this measure, Figure 3 shows the effect of temperature on all of the compressive strength data for the three types of concrete. As shown in Figure 3, the center of the $1.5 \mathrm{~m}$ deep wall made under summer conditions with OPC has a 3-day compressive strength which is $108 \%$ that cured under standard conditions. By contrast, specimens from the center of $1.5 \mathrm{~m}$ wall made with BPC and FPC have 

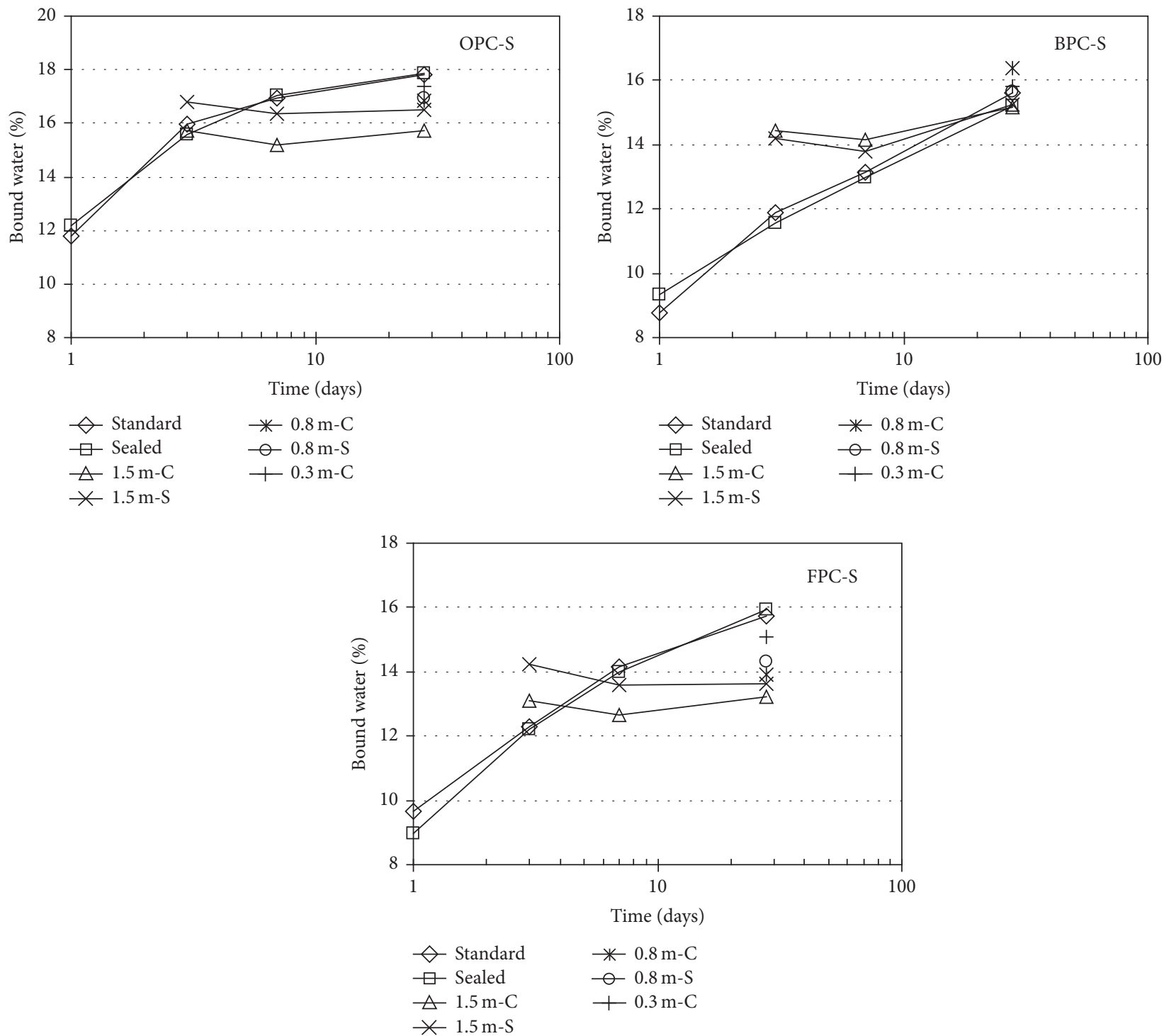

FIGURE 5: Effect of temperature on the bound water of concrete in summer experiments.

a 3-day compressive strength which was $180 \%$ and $176 \%$ of the standard. At 91 days, however the strength ratios dropped to $77 \%, 79 \%$, and $77 \%$ of the standard, respectively, for the OPC, BPC, and FPC samples. The strength development of the core specimen made with OPC was not related to the maximum internal temperature at early ages. However, the use of belite-rich Portland cement and fly ash significantly increased the strength development at high temperatures. Figure 4 shows the results of compressive strength tests of concrete cured under winter weather conditions. The 3-day compressive strength at the center of $1.5 \mathrm{~m}$ deep wall made using OPC is $125 \%$ that concrete made under standard curing conditions. The center of $1.5 \mathrm{~m}$ wall made with BPC and FPC had 3-day compressive strengths which were $162 \%$ and 135\% that of the standard sample. At 91 days. However, the strength ratios were $90 \%, 87 \%$, and $83 \%$ for OPC, BPC, and $\mathrm{FPC}$, respectively. The strength of winter cured concrete first fell down below that of the standard samples at 7 days.

3.3. Hydration Products. Figure 5 shows the change in the amount of bound water in the hydration products for the material produced under summer weather conditions. The amount of bound water in the core specimen cured at high temperature was larger than that of the standard specimen at early ages. However, after 7 days, in the OPC sample, and after 28 days, in the BPC and FPC samples, bound water content of these core specimens was lower than that of the standard specimen. Rodger and Groves [21] suggested that hydration at normal temperatures provides sufficient time for the hydration product to diffuse and precipitate relatively uniformly throughout the interstitial space between the cement grains. But accelerated hydration 

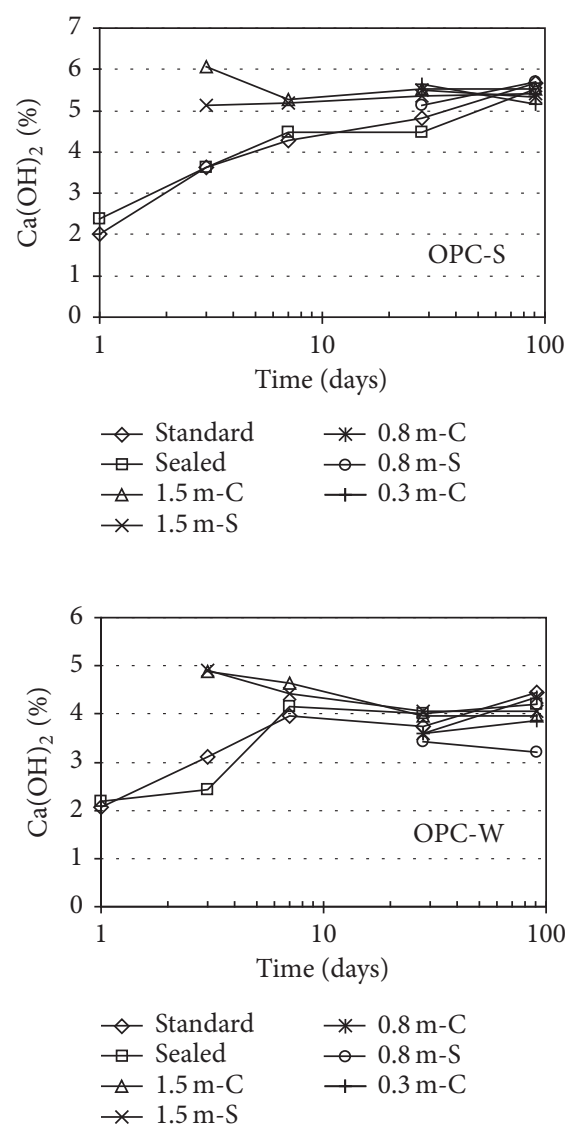

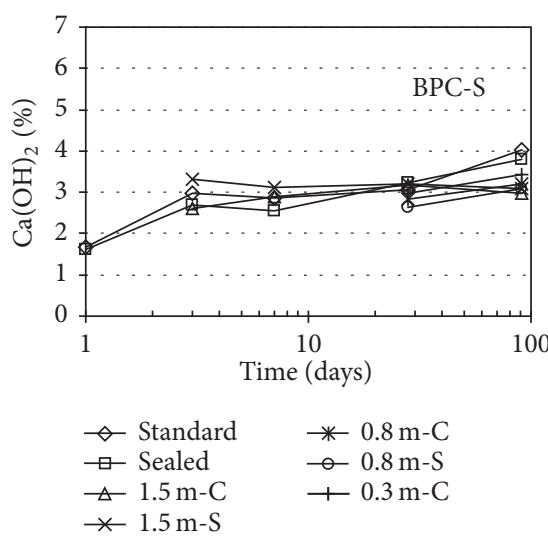

(a)

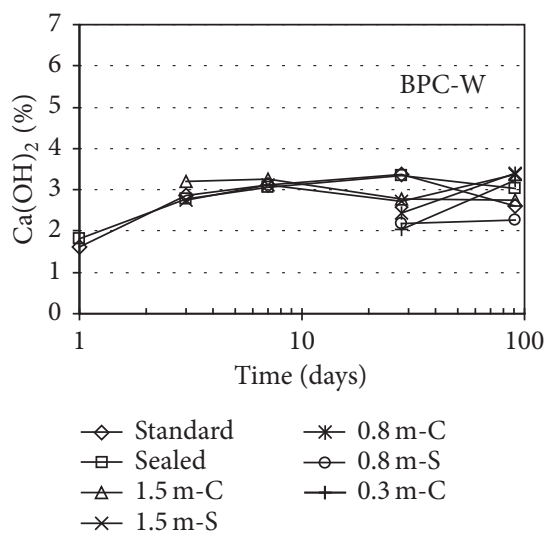

(b)
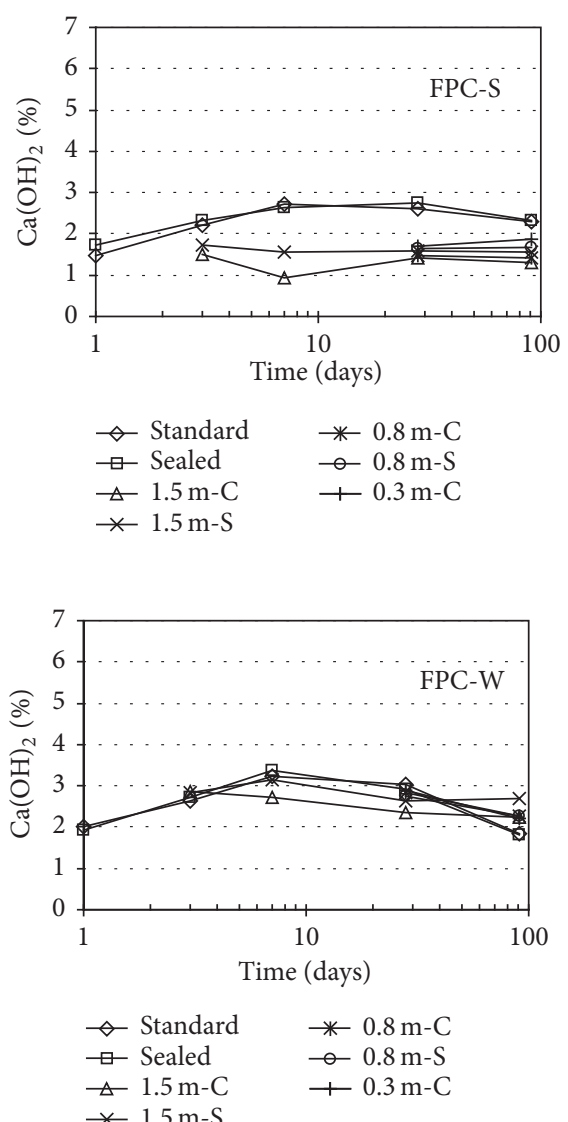

FIgURE 6: (a) Amount of calcium hydroxide of concrete in summer experiments. (b) Amount of calcium hydroxide of concrete in winter experiments.

by an increased curing temperature does not allow time for the diffusion of the hydrates. Consequently, it will produce a high nonuniform distribution of the hydrated products in the paste. The nonuniformity causes a reduction of strength at long curing times. The addition of fly ash increases the bound water content at early ages for the core specimen cured at high temperature perhaps because a rise in curing temperature speeds up the rates of the cement hydration and pozzolanic reactions. The pozzolanic reaction contributes to a decrease in the calcium ion concentration in the liquid phase, attributed to an acceleration of calcium dissolution from the cement grains [26].

The change in the amount of calcium hydroxide is shown in Figures 6(a) and 6(b). The amount of calcium hydroxide in the core specimen made with the OPC is higher than that of the standard specimen because it is directly related to the degree of hydration. In a mass structure, the higher temperature leads to an increase in the degree of hydration. However, no significant difference in calcium hydroxide content was found in any of the BPC specimens. The use of fly ash reduces the amount of the calcium hydroxide due to the pozzolanic reaction and so samples made with FPC showed less calcium hydroxide than the standard specimen.
The pozzolanic reaction in FPC accelerates with an increase in the initial internal temperature and so the thicker wall exhibited less calcium hydroxide than the thinner wall.

3.4. Pore Structure. Figures 7(a) and 7(b) show the porosity results as determined by MIP. The total porosity of the OPC-based samples at center of the $1.5 \mathrm{~m}$ deep wall, cured under summer conditions, was $2.3 \%$ less than that of the standard specimen at 3 days. Comparable values for BPC and FPC samples showed $5.0 \%$ and $2.0 \%$ reductions, respectively. After 7 days, the total porosity of the core specimens began to increase with increased concrete temperature. The total porosity of the BPC and FPC materials exhibited a slight increase at 28 days and a significant increase at 91 days. The addition of pozzolanic materials increases the total porosity. Palardy et al. [18] explained that the dissolution of the calcium leaching originates mostly from the calcium hydroxide and the decomposition of ettringite at high temperature which will contribute to the increase in porosity.

The total porosity of concrete made under winter conditions was smaller than that of concrete made under summer conditions. In particular for OPC and BPC samples, the amount of larger pores, greater than $100 \mathrm{~nm}$, was remarkably reduced when compared with summer cured samples. As 

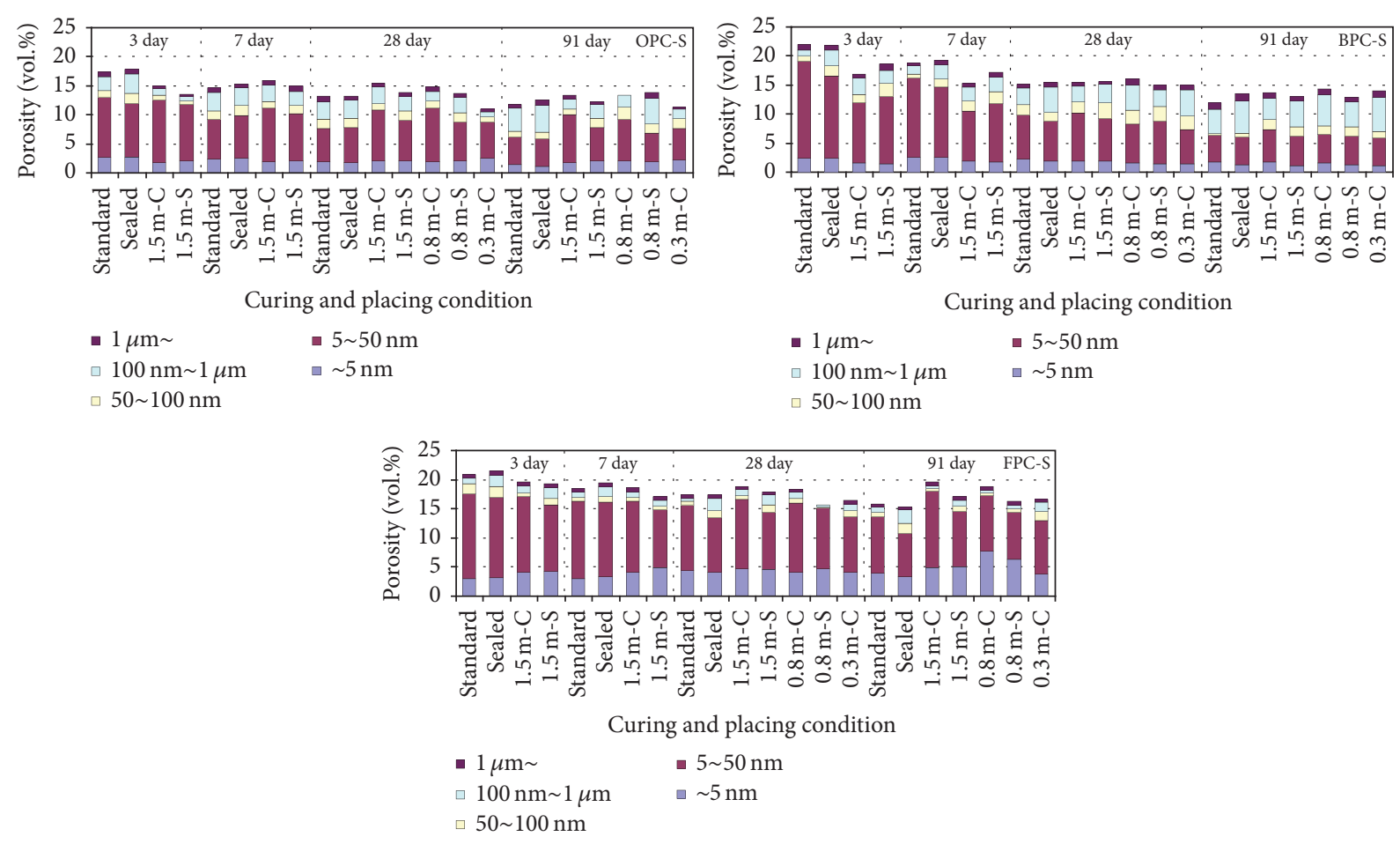

$\begin{array}{ll}\square 1 \mu \mathrm{m} \sim & \square 5 \sim 50 \mathrm{~nm} \\ \square 100 \mathrm{~nm} \sim 1 \mu \mathrm{m} & \square \sim 5 \mathrm{~nm} \\ \square 50 \sim 100 \mathrm{~nm} & \end{array}$

(a)
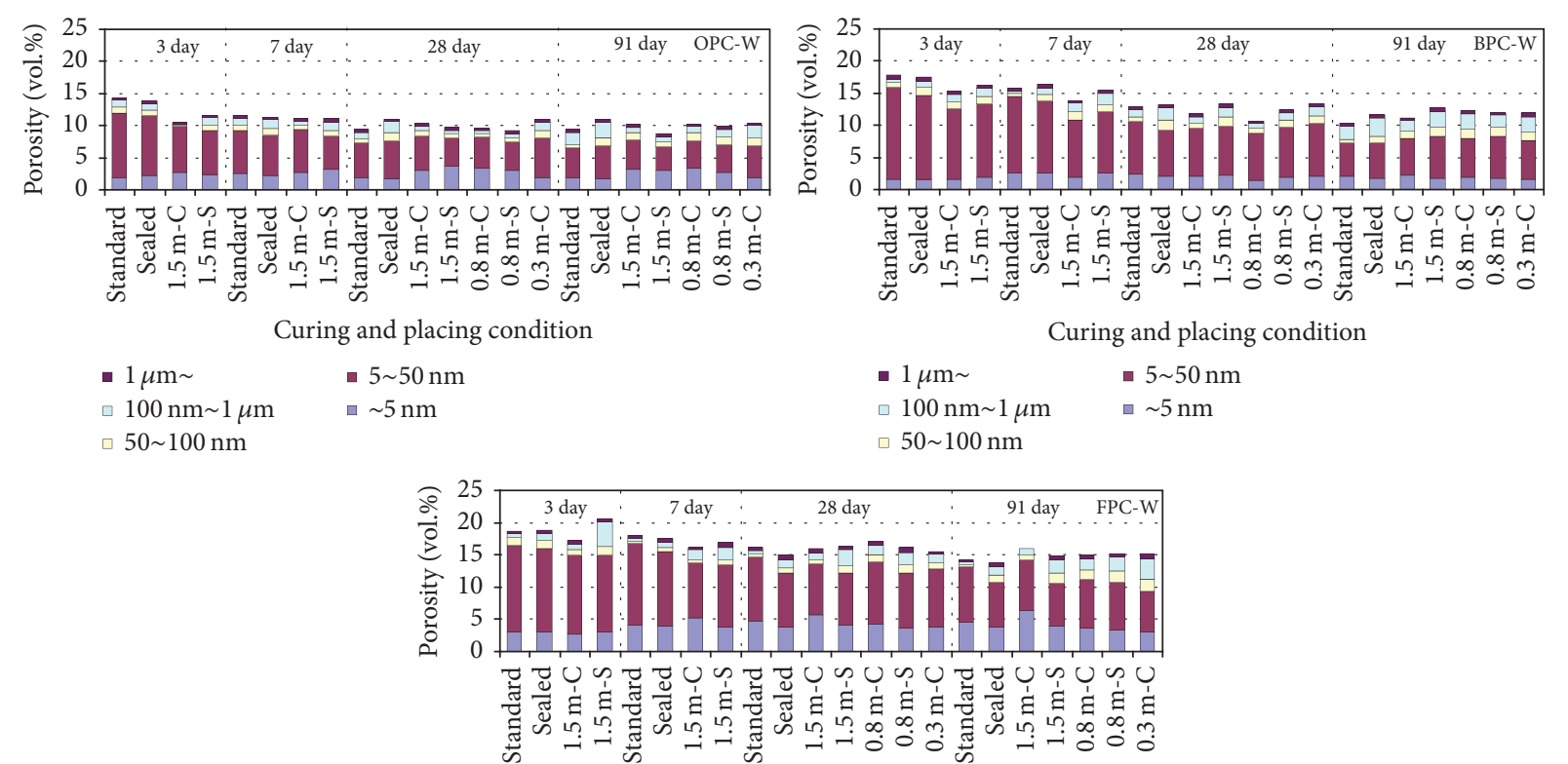

Curing and placing condition

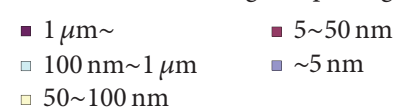

(b)

FIGURE 7: (a) The total porosity and pore size distribution of concrete in summer experiments. (b) The total porosity and pore size distribution of concrete in winter experiments.

shown in Figure 7, the pore size distribution also changed as the concrete temperature increased. With an increase in temperature, the number of larger pores decreased and the number of smaller pores increased, particularly for pores in a size range between 5 and $50 \mathrm{~nm}$ as measured by MIP. This suggests that as the hydration process proceeds, the pore sizes are reduced and the peak of the distribution curve shifts toward small pores. 


\section{Conclusions}

The main conclusions of this paper can be summarized as follows.

(1) The type of cementitious material, the structural member size, and the curing climate were shown to significantly affect the initial internal temperature of mass concrete structures. Elevated temperatures did not affect the early-age strength gain of concrete made with ordinary Portland cement cured under summer weather conditions, but the concrete made with belite-rich Portland cement or fly ash showed a significant increase in early-age strength development. Elevated temperatures resulted in long-term strength loss for all materials.

(2) The bound water content of core specimens cured at elevated temperatures was larger than that of the standard specimen at early ages. However, the bound water content was lower than that of the standard specimen after 7 days for the OPC sample and after 28 days for the BPC and FPC samples. This trend could be correlated to a similar trend in compressive strength.

(3) The use of fly ash in mass concrete structures reduces the amount of calcium hydroxide due to the pozzolanic reaction. The pozzolanic reaction accelerates with an increase in the initial internal temperature and hence less calcium hydroxide was present under summer curing conditions.

(4) The total porosity of the core specimens cured under elevated temperatures was higher than that of the standard specimen. The porosity appeared to rise after 7 days in the OPC material and after 28 days in the BPC and FPC materials. The total porosity of the concrete made under winter weather conditions was smaller than that made under summer weather conditions. Due to the elevated internal temperatures in the structures, the peak of the pore size distribution curve was shifted toward the direction of smaller pores and the number of smaller pores was increased.

\section{Conflicts of Interest}

The authors declare no conflicts of interest.

\section{Acknowledgments}

This work was undertaken as a part of Japan Architecture Standard Specification $5 \mathrm{~N}$ project. This research was partly supported by Kangwon National University (Grant no. 120131429) in South Korea.

\section{References}

[1] K. Maekawa, T. Ishida, and T. Kishi, Multi-Scale Modeling of Structural Concrete, Taylor \& Francis, London, UK, 2009.

[2] I. De La Varga, J. Castro, D. Bentz, and J. Weiss, "Application of internal curing for mixtures containing high volumes of fly ash," Cement and Concrete Composites, vol. 34, no. 9, pp. 1001-1008, 2012.

[3] C. Ozyildirim and W. J. Halstead, "Improved concrete quality with combinations of fly ash and silica fume," ACI Materials Journal, vol. 91, no. 6, pp. 587-594, 1994.
[4] A. Durán-Herrera, C. A. Juárez, P. Valdez, and D. P. Bentz, "Evaluation of sustainable high-volume fly ash concretes," Cement and Concrete Composites, vol. 33, no. 1, pp. 39-45, 2011.

[5] R. Siddique, "Performance characteristics of high-volume Class F fly ash concrete," Cement and Concrete Research, vol. 34, no. 3, pp. 487-493, 2004.

[6] W. F. Price and J. P. Hynes, "In-situ strength testing of high strength concrete," Magazine of Concrete Research, vol. 48, no. 3, pp. 189-197, 1996.

[7] K. Kovler, I. Schamban, S.-I. Igarashi, and A. Bentur, "Influence of mixture proportions and curing conditions on compressive strength of high-performance concrete," ACI Structural Journal, vol. 97, no. 1, pp. 21-26, 2000.

[8] X.-Y. Wang and K.-B. Park, "Analysis of compressive strength development of concrete containing high volume fly ash," Construction and Building Materials, vol. 98, pp. 810-819, 2015.

[9] B. Lothenbach, F. Winnefeld, C. Alder, E. Wieland, and P. Lunk, "Effect of temperature on the pore solution, microstructure and hydration products of Portland cement pastes," Cement and Concrete Research, vol. 37, no. 4, pp. 483-491, 2007.

[10] F. Deschner, B. Lothenbach, F. Winnefeld, and J. Neubauer, "Effect of temperature on the hydration of Portland cement blended with siliceous fly ash," Cement and Concrete Research, vol. 52, pp. 169-181, 2013.

[11] K. De Weerdt, M. B. Haha, G. Le Saout, K. O. Kjellsen, H. Justnes, and B. Lothenbach, "The effect of temperature on the hydration of composite cements containing limestone powder and fly ash," Materials and Structures, vol. 45, no. 7, pp. 1101-1114, 2012.

[12] A. Bentur, R. L. Berger, J. H. Kung, N. B. Milestone, and J. F. Young, "Structural properties of calcium silicate pastes: II, effect of curing temperature," Journal of the American Ceramic Society, vol. 62, no. 7-8, pp. 362-366, 1979.

[13] E. Berodier and K. Scrivener, "Evolution of pore structure in blended systems," Cement and Concrete Research, vol. 73, pp. 25-35, 2015.

[14] S. Jalali and M. Y. Abyaneh, "Prediction of final concrete strength in hot climates," Magazine of Concrete Research, vol. 47, no. 173, pp. 291-297, 1995.

[15] B. Lothenbach, K. Scrivener, and R. D. Hooton, "Supplementary cementitious materials," Cement and Concrete Research, vol. 41, no. 12, pp. 1244-1256, 2011.

[16] K. O. Kjellsen, R. J. Detwiler, and O. E. Gjørv, "Pore structure of plain cement pastes hydrated at different temperatures," Cement and Concrete Research, vol. 20, no. 6, pp. 927-933, 1990.

[17] I. Odler and Y. Chen, "Effect of cement composition on the expansion of heat-cured cement pastes," Cement and Concrete Research, vol. 25, no. 4, pp. 853-862, 1995.

[18] D. Palardy, M. Onofrei, and G. Ballivy, "Microstructural changes due to elevated temperature in cement based grouts," Advanced Cement Based Materials, vol. 8, no. 3-4, pp. 132-138, 1998.

[19] E. Gallucci, X. Zhang, and K. L. Scrivener, "Effect of temperature on the microstructure of calcium silicate hydrate (C-S-H)," Cement and Concrete Research, vol. 53, pp. 185-195, 2013.

[20] X.-Y. Wang and H.-S. Lee, "Evaluation of the mechanical properties of concrete considering the effects of temperature and aging," Construction and Building Materials, vol. 29, pp. 581590, 2012.

[21] S. A. Rodger and G. W. Groves, "The microstructure of tricalcium silicate/pulverized-fuel ash blended cement pastes," Advances in Cement Research, vol. 1, no. 2, pp. 84-91, 1988. 
[22] K. L. Scrivener and H. F. W. Taylor, "Delayed ettringite formation: a microstructural and microanalytical study," Advances in Cement Research, vol. 5, no. 20, pp. 139-146, 1993.

[23] C. D. Lawrence, "Mortar expansions due to delayed ettringite formation. Effects of curing period and temperature," Cement and Concrete Research, vol. 25, no. 4, pp. 903-914, 1995.

[24] J. Khunthongkeaw and S. Tangtermsirikul, "Model for simulating carbonation of fly ash concrete," Journal of Materials in Civil Engineering, vol. 17, no. 5, pp. 570-578, 2005.

[25] A. L. A. Fraay, J. M. Bijen, and Y. M. de Haan, "The reaction of fly ash in concrete a critical examination," Cement and Concrete Research, vol. 19, no. 2, pp. 235-246, 1989.

[26] R. J. Detwiler, C. A. Fapohunda, and J. Natale, "Use of supplementary cementing materials to increase the resistance to chloride ion penetration of concretes cured at elevated temperatures," ACI Materials Journal, vol. 91, no. 1, pp. 63-66, 1994. 

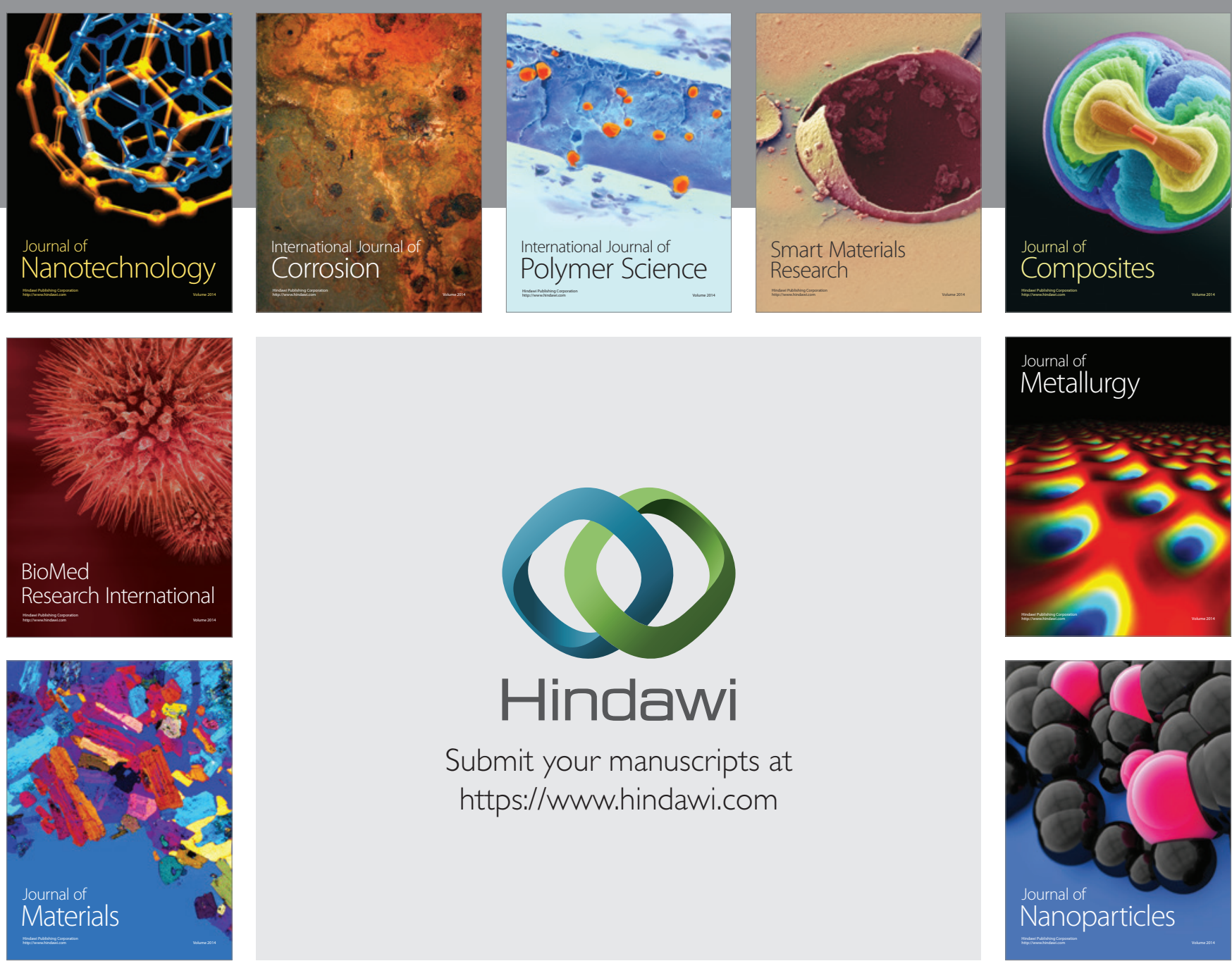

\section{Hindawi}

Submit your manuscripts at

https://www.hindawi.com

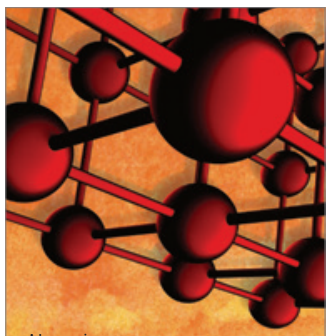

Materials Science and Engineering
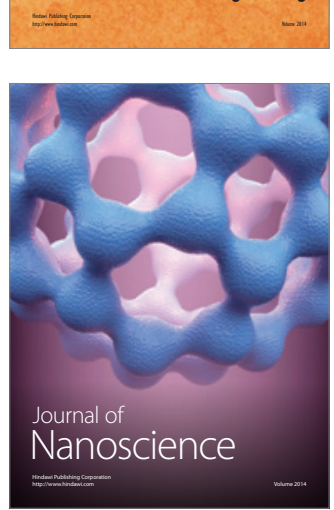
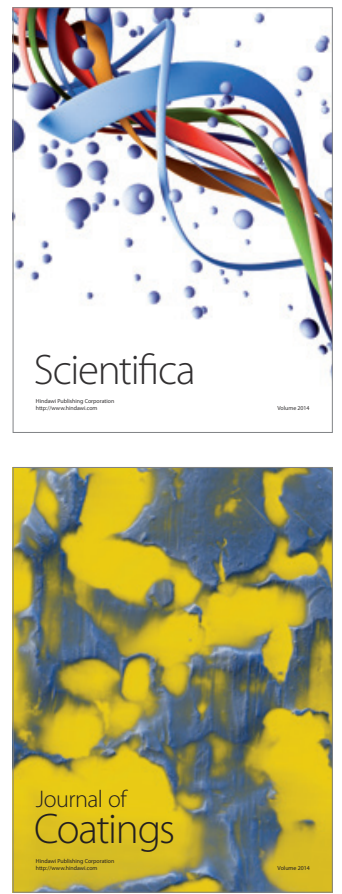
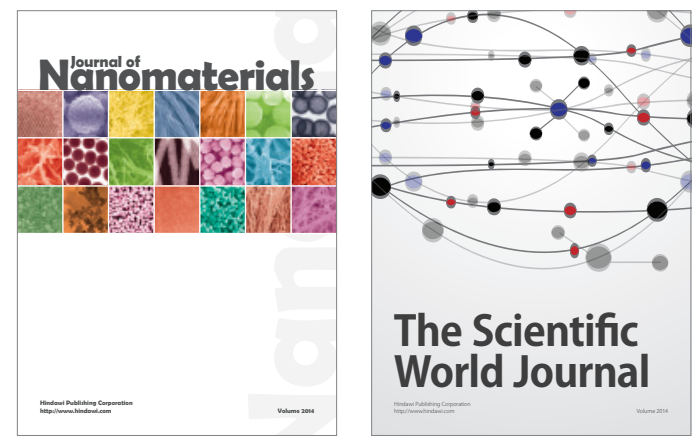

The Scientific World Journal
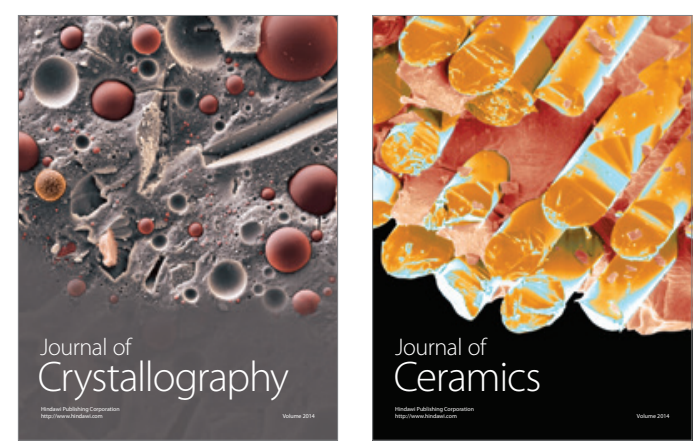
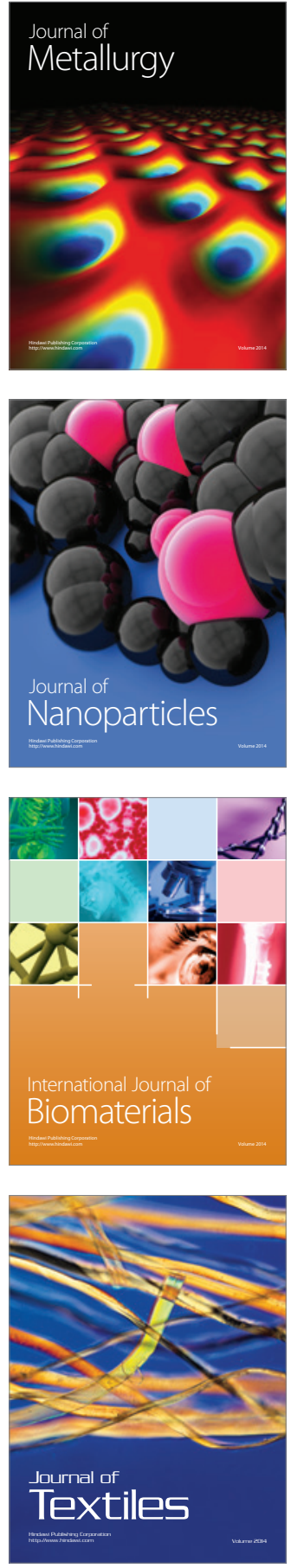